\title{
KEWAJIBAN PELAYANAN PUBLIK OLEH PEMERINTAH DAERAH DI ERA OTONOMI
}

\author{
ACHMADI \\ Dosen Program Studi Al-Ahwal Al-Syakshyiyyah Fakultas Agama Islam \\ Universitas Muhammadiyah Palangkaraya
}

\begin{abstract}
In addressing policy and implementation of regional autonomy needs to be done real efficiency of governance is the implementation of the public service as it should be by apparatus/bureaucracy in a rational institutional network, which will be able to meet the challenges of public service in the implementation of regional autonomy for achieving good governance.

Fore in order to provide the knowledge, expertise, skills and attitude to be able to perform duties in a professional office with based on personality and ethics, creating and apparatus that is capable of acting as a reformer and adhesive national unity, establishing the attitude and spirit of service-oriented services, shelter opinion and community empowerment, ${ }^{1}$ creating a common vision and mindset dynamics in performing general administration tasks and development for the realization of good governance.
\end{abstract}

Keywords: public service, local government

\section{ABSTRAK}

Dalam menyikapi kebijakan dan implementasi dari otonomi daerah perlu dilakukan efisiensi pemerintahan yang nyata dari pelaksanaan pelayanan publik sebagaimana mestinya dan peralatan yang berada di dalam jaringan kelembagaan birokrasi yang rasional, yang akan dapat memenuhi tantangantantangan pelayanan publik dalam pelaksanaan otonomi daerah untuk mencapai pemerintahanan yang baik

Kedepan dalam rangka untuk memberikan pengetahuan, keahlian, keterampilan dan sikap untuk dapat melakukan tugas-tugas di sebuah kantor dengan profesional sesuai dengan kepribadian dan etika, dan menciptakan aparat yang mampu bertindak sebagai seorang pembaharu dan perekat persatuan nasional, membangun sikap dan semangat pelayanan jasa, penampungan pendapat dan pemberdayaan masyarakat, menciptakan kesamaan pandangan dan dinamika pola pikir dalam melaksanakan tugas dan untuk pengembangan administrasi umum penyelenggaraan pemerintahan yang baik.

Kata kunci: pelayanan publik, pemerintah daerah

\section{PENDAHULUAN}

Globalisasi telah membuat banyak negara mempunyai banyak paradigma baru, tidak terkecuali Indonesia yang terus mereformasi diri untuk memberi pelayanan kepada semua pemangku kepentingan (stakeholder) mulai dari pemerintah, masyarakat, dan pelaku bisnis harus sama-sama dapat mengakses kemudahan dan manfaat. Munculnya globalisasi membuat masyarakat saat ini dimanjakan oleh teknologi, khususnya teknologi informasi yang tidak dapat dibendung oleh siapa pun dari anak kecil sampai orang dewasa aktivitas yang dilakukan sehari-hari hendaknya inginnya bersifat instan.

Terwujudnya akuntabilitas pemerintahan dapat dilakukan dengan metode restrukturisasi organissasi lembaga pemerintahan, simplikasi dan otomatisasi, rasionalisasi dan realokasi, regulasi dan deregulasi, peningkatan profesionalitas dan kesejahteraan pegawai. 
[Asmawi Rewansyah, 2010:146] Kemudian Asmawi juga menyebutkan bahwa banyaknya tuntutan masyarakat akan menyulitkan pemerintah dalam membuat prioritas program reformasi birokrasi. Hal ini terjadi akibat berbagai banyak penyimpangan penyelenggaraan pemerintah dan mis-management dalam mengelola aset atau kekayaan negara, memberdayakan, dan melayani masyarakat serta praktik KKN yang sudah lama berlangsung secara sistematik dan meluas.

Selanjutnya mari kita lihat seberapa banyak pelayanan yang diselenggarakan oleh pemerintah khususnya pelayanan yang diberikan oleh pemerintah daerah dalam sistem pemerintahan Indonesia. Dalam konteks kewenangan, pekerjaan pemerintah dan pemerintah daerah telah dibagi dalam urusan-urusan, dimana terdapat 30 urusan yang harus dilayani oleh pemerintah daerah sesuai PP Nomor 30 Tahun 2008.

Tiga puluh urusan layanan tersebut dibagi bersama antara pemerintah, pemerintah provinsi, dan pemerintah kab/kota, kecuali politik luar negeri, pertahanan, keamanan, yustisi, moneter dan fiskal nasional, serta agama yang menjadi tanggung jawab penuh pemerintah pusat. Permasalahan pelayanan publik sebagaimana dijelaskan dalam Undang-Undang Nomor 25 Tahun 2009 masih dihadapkan pada kondisi yang belum sesuai dengan kebutuhan dan perubahan diberbagai kehidupan bermasyarakat, berbangsa, dan bernegara. Hal tersebut dapat disebabkan oleh ketidaksiapan untuk menanggapi terjadinya transformasi nilai yang berdimensi luas serta dampak berbagai masalah pembangunan yang kompleks.
Dalam kajian ini penulis berupaya merumuskan dalam beberapa hal yang pada hakekatnya suatu permasalahan dibangun oleh dua proposisi yang saling berhubungan satu sama lain, baik dalam kerangka hubungan bersifat menerangkan, diterangkan, hubungan sebab akibat dan bersifat fungsional, maka mengaju pada latar belakang masalah tersebut diatas, dapatlah dirumuskan permasalahan adalah 1). Bagaimana kewajiban pelayanan publik untuk pemerintah daerah menurut UndangUndang Nomor 25 Tahun 2009?, 2). Bagaimana pengawasan pelayanan publik oleh pemerintah daerah di era otonomi?

Adapun tujuan dalam kajian ini sebagai salah satu kriteria penelitian yang bersifat ilmiah adalah berhubungan dengan adanya tujuan yang akan dicapai sebagai bentuk proses kontruksi analisis guna mendapatkan kebenaran keilmuan terhadap isu hukum yang diketengahkan, sehingga dengan dilakukannya penulisan ini maka ada beberapa tujuan yang ingin dicapai oleh penulis yaitu 1). Mendeskripsikan dan menganalisis kewajiban pelayanan publik untuk pemerintah daerah menurut Undang-Undang Nomor 25 Tahun 2009, 2). Mendeskripsikan dan menganalisis pengawasan pelayanan publik oleh pemerintah daerah di era otonomi.

\section{METODOLOGI}

\section{Metode Pendekatan}

Penelitian ini menggunakan metode pendekatan yang bersifat Yuridis Normatif yaitu suatu bentuk penelitian yang menekankan pada pemahaman dan pengkajian akan bahan hukum primer yang berupa asas-asas hukum khususnya 
kaedah-kaedah hukum berupa peraturan perundang-undangan serta ketentuan-ketentuan yang berhubungan dengan ruang lingkup permasalahan evaluasi dan pengelolaan fungsi pelayanan publik pemerintah daerah di era otonomi.

\section{Jenis Penelitian}

Penelitian ini dilakukan dan ditujukan untuk mendapat sisi teoritis maupun doktrin-doktrin hukum dengan mengandalkan bahan-bahan dari buku-buku literatur peraturan perundangundangan, majalah dan surat kabar yang mempunyai relevansi serta memberikan gambaran yang jelas tentang masalah yang akan dibahas, dalam bentuk data sekunder yang berupa:

a. Bahan Hukum Primer, terdiri dari peraturan perundang-undangan yang berkaitan dengan masalah yang diteliti, diantaranya:

1) Undang-Undang Dasar 1945

2) Undang-Undang Nomor 25 Tahun 2009 Tentang Pelayanan Publik.

b. Bahan Hukum Sekunder, berupa tulisan-tulisan ilmiah dari para pakar yang memberikan penjelasan mengenai bahan hukum primer seperti hasil-hasil penelitian, karya tulis dari kalangan hukum.

c. Bahan Hukum Tersier atau bahan hukum penunjang, mencakup bahan-bahan yang memberi petunjuk-petunjuk maupun penjelasan terhadap hukum primer dan hukum sekunder, seperti kamus hukum, kamus bahasa, artikel-artikel pada surat kabar.

\section{Pengolahan dan Analisa Bahan Hukum}

Berbagai peraturan perundang-undangan dan bahan pustaka yang telah diperoleh dari sumber yang terkait, kemudian diolah dan dianalisis dengan mempergunakan langkahlangkah normatif dan pembahasan dilakukan secara deskriptif analitik.

Untuk pengolahan bahan hukum primer dilakukan dengan cara memilih pasal-pasal yang berkaitan dengan Perlindungan Hukum, dilanjutkan dengan membuat sistematik dari pasal-pasal dimaksud serta menganalisisnya berdasarkan Hukum.

Hal yang sama juga dilakukan terhadap bahan pustaka, yaitu melakukan klasifikasi dan sistematisasi konsep terbaru atau pendapatpendapat yang berhubungan dengan Kewajiban Pelayanan Publik Oleh Pemerintah Daerah Di Era Otonomi.

Selanjutnya setelah dilakukan pengolahan bahan hukum, maka bahan hukum tersebut dibahas dengan metode analisis teks atau isi (content analysis), yakni menyoroti teks atau isi kaidah-kaidah hukum dari peraturan perundangundangan yang berhubungan dengan objek yang diteliti dengan cara penafsiran (interpretasi) atau hermenuetik, dan sistematisasi (atau menggunakan analisis kualitatif). 


\section{HASIL DAN PEMBAHASAN}

\section{Pengertian Pelayanan Publik Pemerintahan yang Baik (Good Governance)}

Dalam Undang-Undang Pelayanan Publik terdapat pengertian pelayanan publik merupakan kegiatan atau rangkaian kegiatan dalam rangka pemenuhan kebutuhan pelayanan sesuai dengan peraturan perundang-undangan bagi setiap warga negara dan penduduk atas barang, jasa, dan/atau pelayanan administratif yang disediakan oleh penyelenggara pelayanan publik. [Pasal 1 Undang-Undang Republik Indonesia Nomor 25 Tahun 2009 tentang Pelayanan Publik]

Pelayanan publik atau pelayanan umum dapat didefinisikan sebagai segala bentuk jasa pelayanan, baik dalam bentuk barang publik maupun jasa publik yang pada prinsipnya menjadi tanggung jawab dan dilaksanakan oleh Instansi Pemerintah di Pusat, di Daerah, dan di lingkungan Badan Usaha Milik Negara atau Badan Usaha Milik Daerah, dalam rangka upaya pemenuhan kebutuhan masyarakat maupun dalam rangka pelaksanaan ketentuan peraturan perundang undangan. [Lihat http.www//wikipedia_pengertian pelayanan publik.go.id. diakses tanggal 21 Maret 2013]

\section{Pelayanan Publik Menurut Keputusan Menteri Pendayagunaan Aparatur Negara (MenPAN) Nomor 63/KEP/M.PAN/7/2003}

"Segala kegiatan pelayanan yang dilaksanakan oleh penyelenggara pelayanan publik sebagai upaya pemenuhan kebutuhan penerima pelayanan maupun pelaksanaan ketentuan peraturan perundang undangan". (Keputusan Menteri Pendayagunaan Aparatur
Negara (MenPAN) Nomor 63/KEP/M.PAN/7/2003) Pelayanan publik dapat juga diartikan sebagai pemberian layanan (melayani) keperluan orang atau masyarakat yang mempunyai kepentingan pada organisasi itu sesuai dengan aturan pokok dan tata cara yang telah ditetapkan. Pada hakikatnya, pemerintah adalah pelayanan kepada masyarakat. la tidaklah diadakan untuk melayani dirinya sendiri, tetapi untuk melayani masyarakat serta menciptakan kondisi yang memungkinkan setiap anggota masyarakat mengembangkan kemampuan dan kreativitasnya demi mencapai tujuan bersama

\section{Korelasi Antara Pelayanan Publik dan Good Governance}

Good governance yang dimaksud adalah merupakan proses penyelenggaraan kekuasaan negara dalam melaksanakan penyediaan public good and service disebut governance (pemerintah atau kepemerintahan), sedangkan praktek terbaiknya disebut "good governance" (kepemerintahan yang baik). Agar "good governance" dapat menjadi kenyataan dan berjalan dengan baik, maka dibutuhkan komitmen dan keterlibatan semua pihak yaitu pemerintah dan masyarakat. Good governance yang baik menuntut adanya "alignment" (koordinasi yang baik dan integritas, profesionalitas dan etos kerja dan moral yang tinggi. Dengan demikian penerapan konsep "good governance" dalam penyelenggaraan kekuasaan pemerintah negara merupakan tantangan tersendiri. 


\section{Konsep Good Governance}

Konsep good governance ini munculnya karena adanya ketidakpuasan pada kinerja pemerintahan yang selama ini dipercaya sebagai penyelengggara urusan publik. Pendekatan penyelenggaraan urusan publik yang bersifat sentralis, non partisifatif serta tidak akomodatif terhadap kepentingan publik pada rezim-rezim terdahulu, harus diakui telah menumbuhkan rasa tidak percaya dan bahkan antipati pada rezim yang berkuasa. Menurut Edelman, hal seperti ini merupakan era anti birokrasi, era anti pemerintah, Penerapan prinsip-prinsip good governance sangat penting dalam pelaksanaan pelayanan publik untuk meningkatkan kinerja aparatur negara [Marc. Edelman, 1966:171]

Pemerintahan yang baik (good governance) merupakan isu sentral yang paling mengemuka dalam pengelolaan administrasi publik dewasa ini. Tuntutan gencar yang dilakukan oleh masyarakat oleh masyarakat kepada pemerintah untuk melaksanakan penyelengaraan pemerintahan yang baik adalah sejalan dengan meningkatnya tingkat pengetahuan dan pendidikan masyarakat, selain adanya pengaruh globalisasi. Pola lama penyelenggaraan pemerintah, kini sudah tidak sesuai lagi dengan tatanan masyarakat yang telah berubah. Oleh karena itu, tuntutan ini hal yang wajar dan seharusnya direspon oleh pemerintah melakukan perubahan terarah terwujudnya penyelenggaraan pemerintah yang baik.

Arti good dalam good governance mengandung dua pengertian sebagai berikut. Pertama, nilai yang menjunjung tinggi keinginan atau kehendak rakyat, dan nilai yang dapat meningkatkan kemampuan rakyat dalam pencapaian tujuan (nasional), kemandirian, pembangunan berkelanjutan dan keadilan sosial. Kedua, aspek fungsional dari pemerintahan yang efektif dan efisien dalam pelaksanaan tugasnya untuk mencapai tujuan tersebut.

Faktor-faktor yang mempengaruhi pelaksanaan Otonomi untuk dapat melaksanakan tugas otonomi dengan sebaik-baiknya, diantaranya yaitu terhadap : a). Manusia pelaksananya harus baik, b). Keuangan harus cukup dan baik, c). Peralatannya harus cukup dan baik, dan d). Organisasi dan manajemennya harus baik.

Dari pernyataan diatas dapatlah ditarik kesimpulan bahwa agar otonomi daerah dapat dilaksanakan dengan baik, maka diperlukan organisasi dan manajemen pemerintahan daerah yang baik pula. Manajemen pemerintahan daerah yang baik tergantung pada kepala daerah (beserta staffnya) dalam menggerakan peralatan se-efisien dan se-efektif mungkin untuk mencapai tujuan yang telah ditetapkan undangundang.

\section{KESIMPULAN DAN SARAN}

\section{Kesimpulan}

Berdasarkan hasil penelitian dan pembahasan, maka dapat ditarik kesimpulan yang merupakan jawaban dari permasalahan, yaitu :

1. Dalam Undang-Undang Nomor 25 Tahun 2009 tentang Pelayanan Publik telah menghubungkan antara tata-pemerintahan yang baik dengan pelayanan publik melalui konsep good-governance (tata-pemerintahan yang baik) dengan konsep public service (pelayanan publik) berguna untuk 
memperkuat demokrasi dan hak asasi manusia, mengurangi tingkat kemiskinan dan memperdalam kepercayaan pada pemerintahan dan administrasi publik, betapa sangat pentingya pelayanan publik mempengaruhi tingkat kesejahteraan rakyat.

2. Keberhasilan penyelenggaraan otonomi daerah sangat ditentukan oleh kesiapan dan kemampuan daerah itu sendiri dalam mengelola dan memberdayakan seluruh potensi dan sumber daya yang tersedia. Yang berawal dari pelaksanaan otonomi daerah yaitu terselenggaranya pemerintahan yang good governance akan menghasilkan birokrasi yang handal dan profesional, efisien, produktif serta memberikan pelayanan prima kepada masyarakat. Pemerintah pusat telah memberikan pelimpahan wewenang kepada pemerintah daerah memungkinkan terjadinya penyelenggaraan pelayanan dengan jalur birokrasi yang lebih ringkas dan memberikan peluang bagi pemerintah daerah dalam pemberian dan peningkatan kualitas layanan.

\section{Saran}

1. Kedepan diharapkan Pemerintah sebagai Organisasi Penyelenggara berkewajiban menyelenggarakan pelayanan publik sesuai dengan tujuan pembentukan meliputi pelaksanaan pelayanan, pengelolaan pengaduan masyarakat, pengelolaan informasi, pengawasan internal, penyuluhan kepada masyarakat dan pelayanan konsultasi.dan agar dapat memberikan pengetahuan, keahlian, keterampilan dan sikap untuk dapat melaksanakan tugas jabatan secara profesional dengan dilandasi kepribadian dan etika, menciptakan aparatur yang mampu berperan sebagai pembaharu dan perekat persatuan dan kesatuan bangsa, memantapkan sikap dan semangat pengabdian yang berorientasi pada pelayanan, pengayoman dan pemberdayaan masyarakat, menciptakan kesamaan visi dan dinamika pola pikir dalam melaksanakan tugas pemerintahan umum dan pembangunan demi terwujudnya tata kepemerintahan yang baik.

2. Dalam menyikapi kebijakan otonomi daerah dan implementasinya ini perlu segera dilakukan efisiensi penyelenggaraan pemerintahan yang sesungguhnya adalah terselenggaranya pelayanan kepada masyarakat sebagaimana mestinya oleh aparatur/birokrasi dalam suatu jaringan kelembagaan yang rasional, yang akan dapat menjawab tantangan pelayanan masyarakat dalam penyelenggaraan otonomi daerah serta mewujudkan good governance. Kemudian dalam bidang pengawasan terhadap pelayanan publik, diharapkan Ombudsman melaksanakan pengawasan terhadap pelayanan publik tersebut, baik yang diselenggarakan oleh penyelenggara negara dan pemerintahan termasuk yang diselenggarakan oleh Badan Usaha Milik Negara, Badan Usaha Milik Daerah, dan Badan Hukum Milik Negara serta Badan Swasta, maupun perseorangan yang diberi tugas menyelenggarakan pelayanan publik tertentu, yang sebagian atau 
seluruh dananya bersumber dari anggaran

pendapatan dan belanja negara dan

atau anggaran pendapatan dan belanja

daerah.

\section{DAFTAR PUSTAKA}

Asmawi Rewansyah, 2010. Reformasi Birokrasi Dalam Rangka Good Governance, Jakarta, CV. Yusaintanas.

http.www//wikipedia_pengertian pelayanan publik.go.id. diakses tanggal 21 Maret 2013.

Marc. Edelman, 1966. Principle Good Governance, Zolberg, hal, 171.

Undang-Undang Dasar 1945

Undang-undang Nomor 25 Tahun 2009 Tentang Pelayanan Publik. 